\title{
Working
}

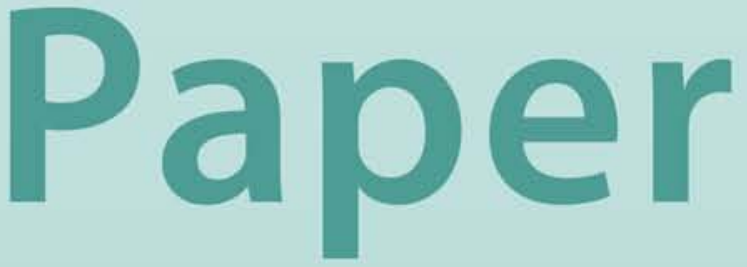




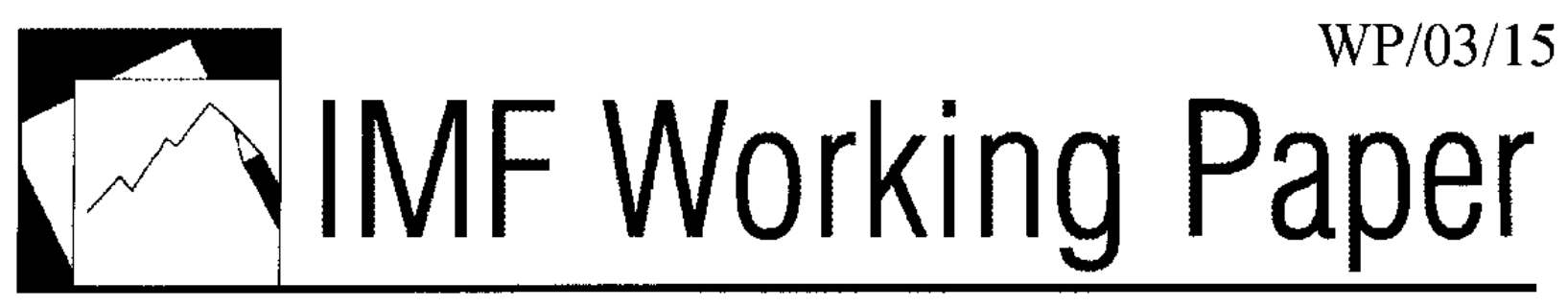

\section{Information Technology and Productivity Growth in Asia}

Il Houng Lee and Yougesh Khatri 


\title{
IMF Working Paper
}

Asia and Pacific Department

\section{Information Technology and Productivity Growth in Asia}

\author{
Prepared by Il Houng Lee and Yougesh Khatri ${ }^{1}$ \\ Authorized for distribution by Kalpana Kochhar
}

January 2003

\begin{abstract}
The views expressed in this Working Paper are those of the author(s) and do not necessarily represent those of the IMF or IMF policy. Working Papers describe research in progress by the author(s) and are published to elicit comments and to further debatc.
\end{abstract}

The contribution of the information and communication technology (ICT) sector to growth in Asian economies is clearly evident from the expenditure side (net exports) and became particularly significant in the second half of the 1990s. This paper employs an extension of the standard growth accounting framework, using estimates of stock of ICT capital (hardware, software, and telecommunications equipment), to estimate the direct contributions to growth. The contribution of ICT to growth in Asia during the 1990s is found to be mainly from capital deepening. Total factor productivity (TFP) is also decomposed (using the dualor revenue-based-approach) into the contributions of non-ICT capital stock, ICT capital stock, and labor. TFP growth is found to be relatively small in most Asian countries.

JEL Classification Numbers: O3, O47

Keywords: Growth, Asia

Author's E-Mail Address: ilee@imf.org; ykhatri@imf.org

${ }^{1}$ Deputy Division Chief and Economist, Asia and Pacific Department, respectively. The authors are grateful to Janice Lee for valuable research assistance, and to seminar participants and reviewers in the Asia and Pacific Department for their comments and suggestions. 


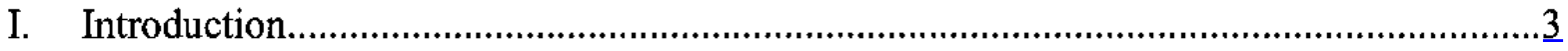

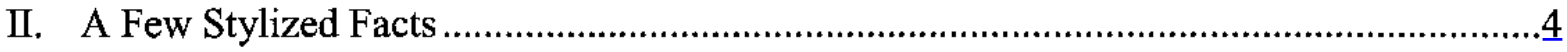

III. Measuring ICT Contribution to Growth of Labor Productivity ......................................5

A. Estimating Factor Contributions to Labor Productivity ...........................................5

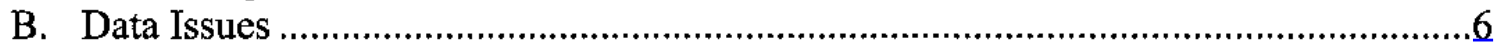

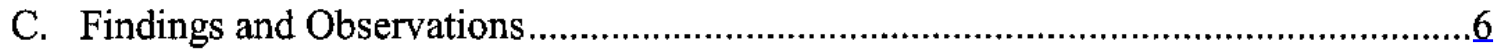

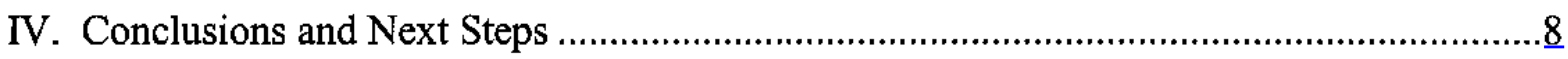

Text Table 1. Capital Stock as Percent of GDP, Average 1992-99 ....................................5

Text Figures:

1. Total ICT Spending, 1992-99 ...........................................................................

2. U.S. Electronic and Electrical Equipment Imports from Selected Countries,

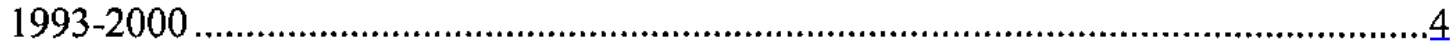

3. Components of Labor Productivity Growth, 1990-94 .............................................

4. Components of Labor Productivity Growth, 1995-99 .............................................

Annexes:

I. Growth Accounting Framework .......................................................................

II. Data Issues ......................................................................................................13

III. Table A1. Estimating Contribution to Growth in the United States and Selected Asian

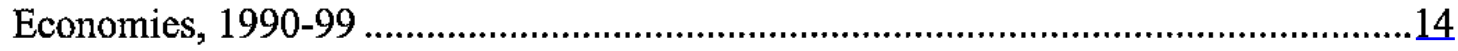

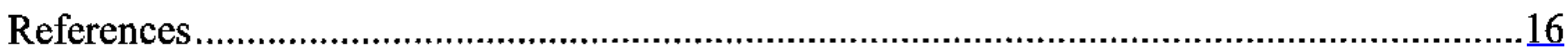




\section{INTRODUCTION}

With the arrival of what is broadly held to be the next technological revolution-information technology - the natural question for economists has been what will be the impact on growth? This question has motivated a recent and growing body of literature. The focus of the initial studies such as Oliner and Sichel (2000) was the United States, where the impact of information and communication technology (ICT) on growth seemed most manifest and for which the required data were available. Subsequently, Goldman Sachs (2000), Daveri (2000), Bassanini et al. (2000), and Cardarelli (2001) have extended the investigation of the impact of ICT on growth to Europe, Japan, and Australia. This study extends the work to developing and emerging Asia, which has been possible with the availability of the IDC/WITSA data (discussed below).

Labor productivity can be augmented through accumulation of ICT capital stock (i.e., capital deepening) and through productivity growth in the ICT sector itself. These can be thought of as the direct impact of ICT on productivity growth. There are however indirect effects of ICT on productivity, through the use of ICT in other sectors. The direct effects of ICT on productivity can be investigated in a simple augmented growth accounting framework, and there exists evidence that ICT is already making an important contribution to labor productivity growth. However, there is currently no general framework for analysis of the indirect effects of ICT on general efficiency of production and thus far less evidence of the more general impact of ICT exists.

There is also some debate in the literature as to the extent of the impact of ICT on growth. Oliner and Sichel (2000) and to a lesser extent, Jorgenson and Stiroh (2000) lean toward the view that ICT has played a significant role in generating a fundamental change in the U.S. economy's growth. Despite some methodological differences, these papers derive similar estimates, attributing around a quarter percentage point of the acceleration in labor productivity since 1995 to ICT (TFP growth in the ICT sector) and a half a percentage point to capital deepening (all of which is attributable to the accumulation of ICT capital). In total, they estimate ICT has contributed three-fourth of the recent labor productivity acceleration.

In contrast, Gordon (2000) and Bosworth and Triplett (2000) adopt the more agnostic view that the ICT "revolution" has not had the same impact as the general-purpose technologies introduced in the past century (such as electricity or transportation). Gordon (2000) focuses on the cyclical component of the US labor productivity surge, suggesting that half of the acceleration after 1995 has been a cyclical phenomenon.

This study finds that the contribution of ICT to growth in Asia during the 1990s is mainly from capital deepening. 


\section{A Few Stylized Facts}

Total spending on ICT capital and services in key Asian economies other than Japan was equivalent to about 14 percent of that in the United States and 30 percent of that in Japan during 1992-99. ${ }^{2}$ Of the 9 Asian economies considered, China and Korea together accounted for more than half of the total ICT spending. For most economies, ICT spending increased in the second half of 1990 s, especially on software where it doubled relative to the amount spent during the first half.

The large spending in the ICT sector

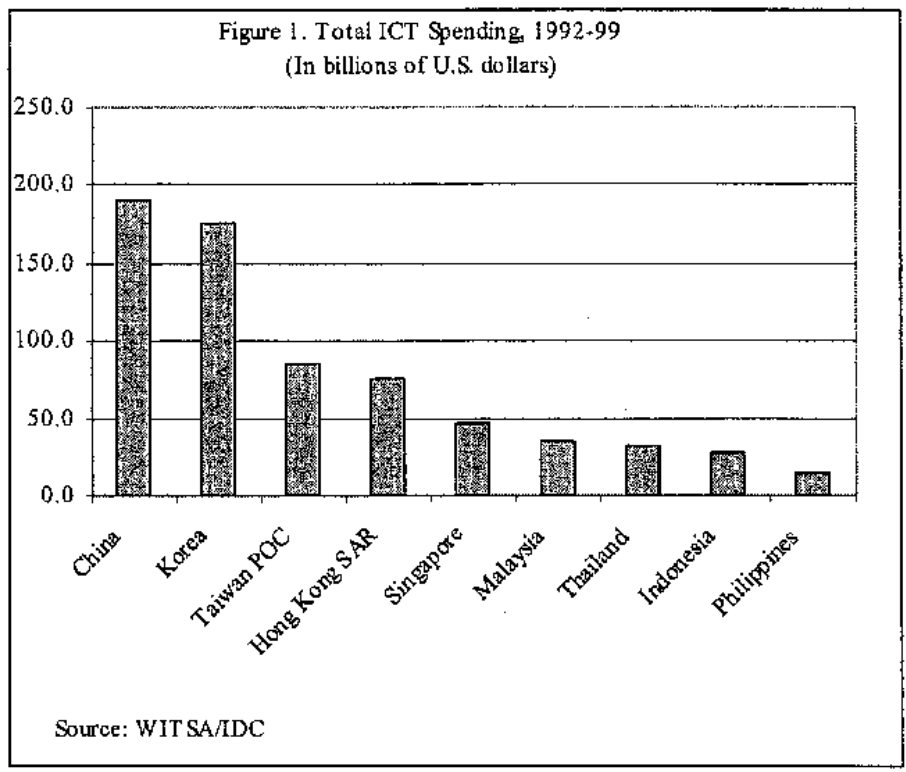
helped some of these economies to recover from the Asian crisis. An important demand factor was the strong U.S. growth and its related demand for electronics during most of the 1990s. Of the 9 Asian economies, Hong Kong SAR was the only net importer of ICT products. The net benefit of electronics exports in some of these economies was, however, modest due to the small value added, and the worsening terms of trade with the decline in the electronic product prices, effectively transferring the gain to the importing countries.

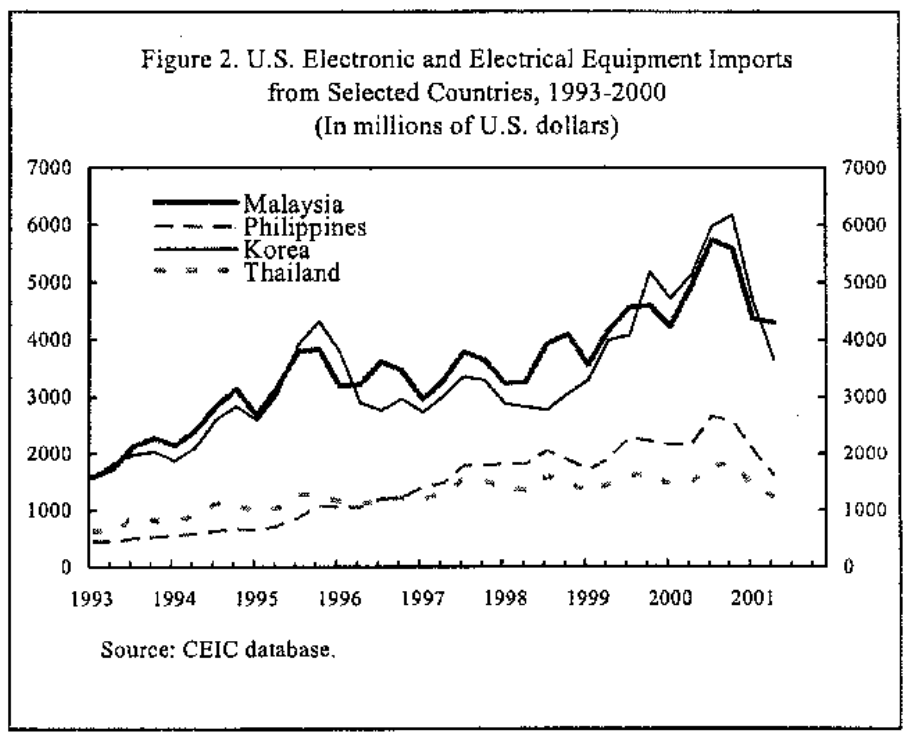

${ }^{2}$ Data comprise spending on hardware, software, IT services (e.g., IT consulting, operations management, IT training and education, processing, and IT support), internal ICT spending (IT operating budget, internally customized software, and other expenses related to IT that cannot be directly tied to a vendor), and other office equipment and telecommunication. Data source: World Information Technology and Services Alliance (WITSA)/International Data Corporation (IDC). 
The ICT capital stock as percent of nonfarm business GDP ${ }^{3}$ averaged 9 percent in the Asian economies, compared with 13 percent of GDP in the United States. While some caution should be exercised in interpreting the capital stock data for individual countries given data weaknesses (see below), the ratio varies greatly with China at $1 \frac{1}{2}$ percent of GDP and Singapore at $21 \frac{1}{2}$ percent of GDP).

\begin{tabular}{|c|c|c|c|c|c|c|c|c|c|c|}
\hline \multicolumn{11}{|c|}{ Table 1. Capital Stock as Percent of GDP, Average 1992-99 } \\
\hline & U.S. & Hong Kong SAR & Indonesia & Korea & Malaysia & Philippines & Singapore & Taiwan POC & Thailand & China \\
\hline Non-ICT capital stock & 149 & 100 & 225 & 73 & 179 & 118 & 72 & 128 & 128 & 172 \\
\hline ICT capital stock & 14 & 19 & 2 & 13 & 8 & 3 & 21 & 10 & 4 & 2 \\
\hline
\end{tabular}

Source: Calculations based on WITSA/DC data.

\section{Measuring ICT Contribution to Growth of Labor Productivity}

ICT contribution to growth, via labor productivity, is measured from capital deepening, ICT production, and spillover to other sectors. First, capital deepening increases labor productivity through a larger capital-labor ratio. Second, ICT production adds to the economy-wide productivity through efficiency gains in the production of ICT goods. Finally, spillover effects have been observed from efficiency gains arising from greater use of ICT technology in the economy, especially in the services sector-e.g., business to business (B2B), even though there is no direct means of measuring these gains.

\section{A. Estimating Factor Contributions to Labor Productivity}

In an extension of the basic growth accounting framework, the Cobb-Douglas production function is specified as the parametric form of equation (A11) in Annex I as follows.

$$
\Delta \ln y=g+\alpha_{K} \Delta \ln k+\alpha_{H} \Delta \ln h+\alpha_{S} \Delta \ln s+\alpha_{T} \Delta t+\alpha_{L} \Delta \ln q
$$

where the uppercase $\mathrm{k}, \mathrm{h}, \mathrm{s}, \mathrm{t}$, and $\mathrm{q}$ are, respectively, non-ICT capital stock, capital stock of hardware, software, and telecommunication, and labor; and $y=\mathrm{Y} / \mathrm{L} ; \mathrm{k}=\mathrm{K} / \mathrm{L} ; \mathrm{h}=\mathrm{H} / \mathrm{L} ; \mathrm{s}=\mathrm{S} / \mathrm{L}$; $\mathrm{t}=\mathrm{T} / \mathrm{L} ; \mathrm{g}$ is the Solow residual, and $\mathrm{q}$ is a quality-adjusted labor index (a detailed description of the data is provided in Annex II). $\alpha_{\mathrm{i}}$ is the income share of input I (calculated, based on available data for each economy).

\footnotetext{
${ }^{3}$ Capital stocks were estimated using the data on ICT spending as a proxy for ICT investment and perpetual inventory method. Total investment excludes construction (or residential buildings in the case of the United States) except for Indonesia, Malaysia, and China, for which data were not available. Likewise, GDP data were also adjusted for construction (and agriculture whenever data was available) except for the three countries.
} 


$$
g=\gamma_{K} \frac{\Delta \ln r}{r}+\gamma_{H} \frac{\Delta \ln h}{h}+\gamma_{S} \frac{\Delta \ln s}{s}+\gamma_{T} \frac{\Delta \ln t}{t}+\gamma_{L} \frac{\Delta \ln w}{w}
$$

where $\gamma$ 's are shares of ICT (hardware, software, and telecommunication), non-ICT capital, and labor of total output.

Here, the sum of contributions from ICT capital deepening is measured by:

$\alpha_{H} \Delta \ln h+\alpha_{S} \Delta \ln s+\alpha_{T} \Delta \ln t$

while efficiency gains from production are measured by:

$\gamma_{H} \frac{\Delta \ln h}{h}+\gamma_{S} \frac{\Delta \ln s}{s}+\gamma_{T} \frac{\Delta \ln t}{t}$

Spillover effects from ICT to overall growth would be subsumed in other terms.

\section{B. Data Issues}

ICT contribution to productivity is estimated using data published by the World Information Technology and Service Alliance based on International Data Corporation (WITSA/IDC). These data are on ICT spending, rather than on investment, but these have been used because their wide coverage of countries, which provides consistency and facilitates comparison across countries. The data on ICT spending, which are in U.S. dollars, were first adjusted for quality improvements using the U.S. hedonic prices produced by the U.S. Bureau of Economic Analysis (BEA), and then converted into national currencies using PPP-based exchange rates to filter out short-term variations of national currencies against the U.S. dollar. (A more detailed description of the data is provided in Annex II).

\section{Findings and Observations}

Applying the above growth accounting framework, we found that ICT capital deepening has played an important role in improving labor productivity in Asia, especially during the second half of the 1990s. During this period, TFP growth however was less significant as the slowdown in capital stock and labor shedding was much more gradual than the drop in real GDP growth.

Labor productivity growth in the selected Asian economies dropped from 5 percent in the first half of $1990 \mathrm{~s}$ to about $2 \frac{1}{2}$ percent in the second half of $1990 \mathrm{~s}$. While contributions from labor quality and, to a lesser extent, non-ICT capital stock also declined, the contribution from ICT capital stock to labor productivity rose from less than 10 percent to almost 30 percent during the same period. These developments contrast somewhat with those 
observed in the United States where the contributions from all factors of production rose in the second half of 1990s in tandem with a pickup in GDP. ${ }^{4}$ Within the overall composition of labor productivity growth in Asia, ICT capital deepening played a predominant role. The contribution from TFP declined from 20 percent to about 3 percent, which contrasts again not only with the United States but also with some of the non-Asian OCED countries. ${ }^{5}$

During the first half of 1990s, contributions to labor productivity from capital deepening in the ICT sector were noteworthy in several economies, including Hong Kong SAR, Singapore, and Korea. The contributions were strengthened further in the second half of 1990s, reflecting not so much an acceleration of ICT investment, but rather the maintenance of a relatively high level of ICT investment during a period of output collapse following the Asian crisis. During both of these periods, Hong Kong SAR, Korea, and Singapore benefited most from capital deepening in part due to the large income share of the ICT capital. In the case of the Philippines, even though capital deepened further in the ICT sector in the second half of 1990s, its contribution to GDP growth remained unchanged as its GDP growth rate was least affected by the Asian crisis in the second half of $1990 \mathrm{~s}$.
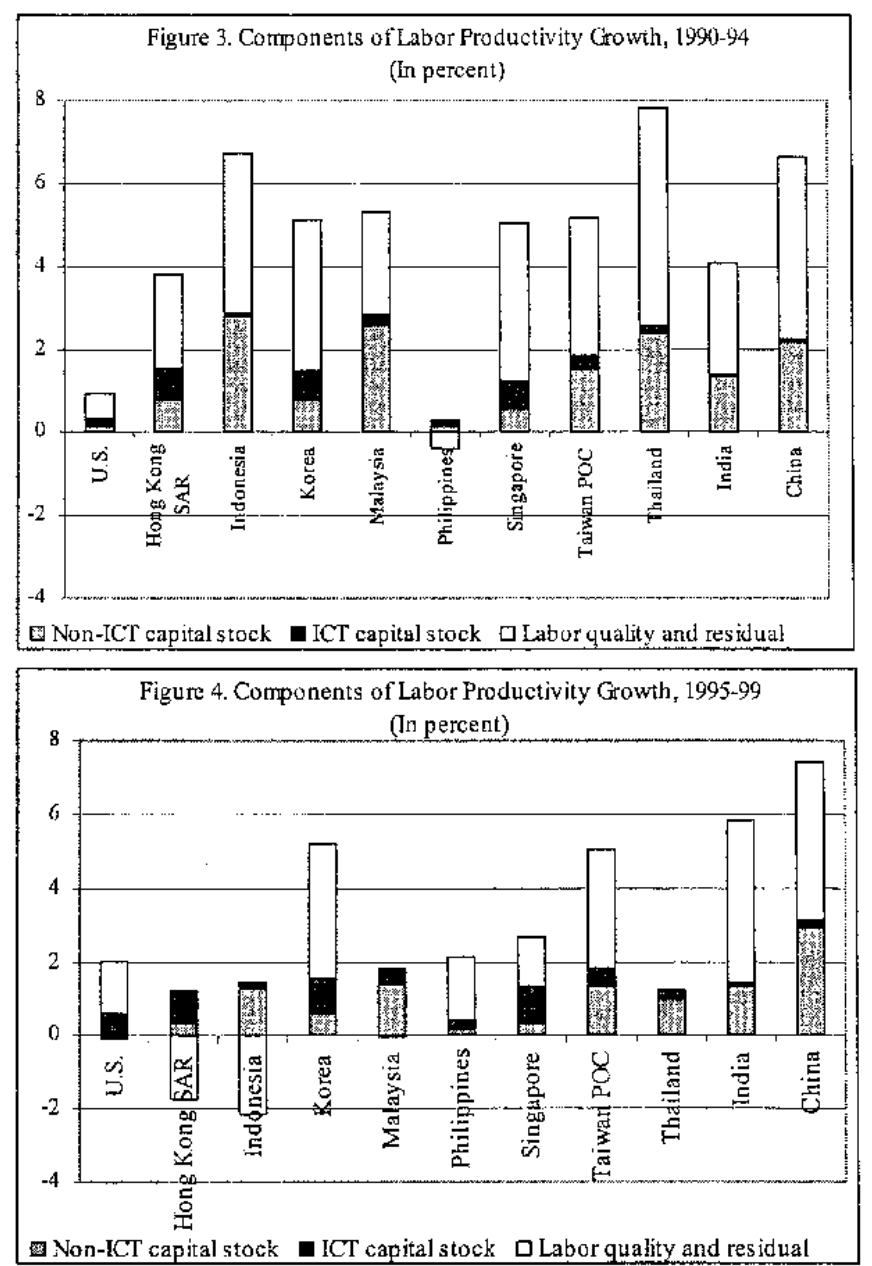

${ }^{4}$ Given the weaknesses of the WITSA/IDC data, ICT contributions to growth for the United States were reestimated and compared with those in recent studies that were based on BEA and Bureau of Labor Statistics (BLS) data. The result shows a lower income share of software and a substantially weaker contribution from ICT production. The former is due to the slow growth in software investment recorded in the WITSA/IDC data relative to those in the BLS data. The latter is in large part due to the slow growth of real rate of return of ICT capital (even though it may be high in absolute terms), and the lower income share of software.

${ }^{5}$ Goldman Sachs (2000). 
Contribution to labor productivity growth from TFP was modest in the first half of 1990s, accounting for 25 percent on average for overall growth. Unlike the contribution from capital deepening, it declined in several Asian economies in the second half of 1990s as the decline in output growth was much sharper than the decline in the capital stock. The decomposition of TFP indicates a modest improvement in the contribution from ICT production. For Korea and China, the contribution from ICT production declined due to a drop in the production of telecommunications equipments. In contrast, the production of telecommunications equipment was the key contributor to TFP growth in the second half of 1990s.

\section{Conclusions AND NeXt StEPS}

Our main conclusion is that the impact of ICT on labor productivity in Asia is currently mainly through capital deepening. As noted in IMF (2001, p.105): "The effects of such revolutions have generally occurred in three (often overlapping) main stages. First, technological change raises productivity growth in the innovating sector; second, falling prices encourage capital deepening; and, finally, there can be significant reorganization of production around the capital goods that embody the new technology." Thus we may expect the bulk of the benefits from ICT in Asia (and the world) to accrue in the future.

The agenda for future work investigating the implications of the ICT sector for growth in Asia would include an assessment of the indirect effects of the ICT sector on productivity and growth (through the use of ICT in other sectors), a refinement of the data usedincluding the development of country-specific hedonic price indices, and alternative methodologies that do not require the imposition of restrictive assumptions such as constant returns to scale. 


\section{Growth Accounting Framework}

\section{Basic framework}

The neoclassical production function is:

$\mathrm{Y}=\mathrm{F}(\mathrm{A}, \mathrm{K}, \mathrm{L})$

where A is the level of technology, $\mathrm{K}$ is the stock of capital, and $\mathrm{L}$ is the labor force.

Differentiating (A1) with respect to time, we obtain:

$$
\frac{d Y}{d t} \frac{1}{Y}=\frac{\partial F}{\partial A} \frac{d A}{d t} \frac{1}{Y}+\frac{\partial F}{\partial K} \frac{d K}{d t} \frac{1}{Y}+\frac{\partial F}{\partial L} \frac{d L}{d t} \frac{1}{Y}
$$

$\left(\mathrm{F}_{\mathrm{A}} / \mathrm{Y}\right)(\dot{\mathrm{g}})$ is the growth due to technological change (Solow residual) and is given as. ${ }^{6}$

$$
\left(\frac{F_{A} A}{Y}\right) \dot{g}=\left(\frac{F_{A} A}{Y}\right) \frac{\dot{A}}{A}=\frac{\dot{Y}}{Y}-\left(\frac{F_{K} K}{Y}\right) \frac{\dot{K}}{K}-\left(\frac{F_{L} L}{Y}\right) \frac{\dot{L}}{L}
$$

Assuming Hicks-neutrality, ${ }^{7} \dot{\mathrm{g}}$ is defined as:

$$
\dot{g}=\frac{\dot{A}}{A}=\frac{\dot{Y}}{Y}-\left(\frac{F_{K} K}{Y}\right) \frac{\dot{K}}{K}-\left(\frac{F_{L} L}{Y}\right) \frac{\dot{L}}{L}
$$

where $A F_{K}$ is the marginal product of capital. If factors are paid their social marginal products, then $A F_{K}=\mathrm{r}=\mathrm{R} / \mathrm{P}$ (the rental price of capital); and $A F_{L}=\mathrm{W}=\mathrm{W} / \mathrm{P}$ (the wage rate).

The dual approach can be derived from the output and factor income equation as follows:

$$
Y=r K+w L
$$

Differentiating (A5) with respect to time, we obtain:

\footnotetext{
${ }^{6}$ A dot over a variable signifies the derivative with respect to $t$.

${ }^{7}$ Technical change is defined as Hicks-neutral if at all points on the expansion paths the marginal rate of technical substitution is independent of time; in other words, the shift of the isoquant does not affect the marginal rate of technical substitution.
} 
$\frac{\dot{Y}}{Y}=\frac{r K}{Y}\left(\frac{\dot{r}}{r}+\frac{\dot{K}}{K}\right)+\frac{w L}{Y}\left(\frac{\dot{w}}{w}+\frac{\dot{L}}{L}\right)$

Substituting (A6) into (A3), we obtain:

$\left(\frac{F_{A} A}{Y}\right) \dot{g}=\left(\frac{F_{K} K-r K}{Y}\right) \frac{\dot{K}}{K}+\left(\frac{F_{L} L-w L}{Y}\right) \frac{\dot{L}}{L}+\frac{r K}{Y}\left(\frac{\dot{r}}{r}\right)+\frac{w L}{Y}\left(\frac{\dot{w}}{w}\right)$

With the Hicks-neutrality assumption, (A7) is defined as:

$\dot{g}=\left(\frac{F_{K} K-r K}{Y}\right) \frac{\dot{K}}{K}+\left(\frac{F_{L} L-w L}{Y}\right) \frac{\dot{L}}{L}+\frac{r K}{Y}\left(\frac{\dot{r}}{r}\right)+\frac{w L}{Y}\left(\frac{\dot{w}}{w}\right)$

If the social marginal products are equal to the corresponding factor incomes, then (A8) becomes:

$\dot{g}=\frac{r K}{Y}\left(\frac{\dot{r}}{r}\right)+\frac{w L}{Y}\left(\frac{\dot{w}}{w}\right)$

This requires that the production function exhibits constant returns to scale as the marginal rate of technical substitution equals the relative factor income. ${ }^{8}$ Alternatively, if we do not normalize by the GDP deflator, i.e., $P Y=R K+W L$, with $x=R / P$ and $w=W / P$, then (A9) can be rewritten as:

$\dot{g}=\frac{r K}{Y}\left(\frac{\dot{R}}{R}\right)+\frac{w L}{Y}\left(\frac{\dot{W}}{W}\right)-\frac{\dot{P}}{P}$

which shows that TFP growth is the difference between the factor share weighted cost of inputs and the price of output.

If, however, the social marginal product of capital is not equal to capital income (rent), then the constant returns to scale assumption does not hold. In particular, if the social marginal product to capital is larger than capital income due to positive externalities (spill overs), then the production function exhibits increasing returns to scale and the Solow residual will overstate the factor productivity increase by:

${ }^{8}$ Equation 4 holds only if the production function exhibits constant returns to scale. 
$\left(\frac{F_{K} K-r K}{Y}\right) \frac{\dot{K}}{K}$

The increasing returns to scale can be expected in an environment whereby a firm's production function $\mathrm{Y}_{\mathrm{i}}$ becomes a function not only of its own employed capital $\mathrm{K}_{\mathrm{i}}$, but also of the economy-wide capital stock $\mathrm{K}$. For example, in a Cobb-Douglas production function, the situation can be reflected in $Y_{i}=A K_{i}^{\alpha} K^{\beta} L_{i}^{1-\alpha}$ for individual firms, and $Y=A K^{\alpha+\beta} L^{1-\alpha}$ for the economy. In such a situation, $\mathrm{AF}_{\mathrm{K}}$ is greater than $\mathrm{r}$.

\section{Extension of the basic framework}

The neoclassical production function framework as shown above is extended by dividing the capital stock into ICT and non-ICT capital:

$\mathrm{Y}=\mathrm{F}(\mathrm{A}, \mathrm{K}, \mathrm{H}, \mathrm{S}, \mathrm{T}, \mathrm{L})$

where $\mathrm{K}$ is the level of non-ICT capital; and $\mathrm{H}, \mathrm{S}$, and $\mathrm{T}$ are the levels of ICT capital (hardware, software, and telecommunications, respectively).

Contributions to growth from the various factors of production are measured by:

$$
\frac{\dot{Y}}{Y}=\dot{g}+\left(\frac{F_{K} K}{Y}\right) \frac{\dot{K}}{K}+\left(\frac{F_{H} H}{Y}\right) \frac{\dot{H}}{H}+\left(\frac{F_{S} S}{Y}\right) \frac{\dot{S}}{S}+\left(\frac{F_{T} T}{Y}\right) \frac{\dot{T}}{T}+\left(\frac{F_{L} L}{Y}\right) \frac{\dot{L}}{L}
$$

where g, under the Hicks-neutrality assumption, is defined as:

$$
\dot{g}=\frac{\dot{A}}{A}=\frac{\dot{Y}}{Y}-\left(\frac{F_{K} K}{Y}\right) \frac{\dot{K}}{K}-\left(\frac{F_{H} H}{Y}\right) \frac{\dot{H}}{H}-\left(\frac{F_{S} S}{Y}\right) \frac{\dot{S}}{S}-\left(\frac{F_{T} T}{Y}\right) \frac{\dot{T}}{T}-\left(\frac{F_{L} L}{Y}\right) \frac{\dot{L}}{L}
$$

Using the dual approach, the Solow residual can be broken down into:

$$
\dot{g}=\frac{R K}{P_{K} Y}\left(\frac{\dot{r}}{r}\right)+\frac{R H}{P_{H} Y}\left(\frac{\dot{h}}{h}\right)+\frac{R S}{P_{S} Y}\left(\frac{\dot{s}}{s}\right)+\frac{R T}{P_{T} Y}\left(\frac{\dot{t}}{t}\right)+\frac{W L}{P Y}\left(\frac{\dot{w}}{w}\right)
$$

where $h, s, t$ represent rental prices of the three respective ICT capital, and $P_{i}$ 's represent final product prices where $\mathrm{i}=\mathrm{K}, \mathrm{H}, \mathrm{S}$, and $\mathrm{T}$.

To estimate TFP growth of a sector, e.g., telecommunication sector T, we need the value added as well as the respective inputs to that sector. Assume, for the sake of simplicity, that $\mathrm{K}_{\mathrm{T}}$ and $\mathrm{L}_{\mathrm{T}}$ are inputs for sector $\mathrm{T}$, i.e., $\mathrm{Y}_{\mathrm{T}}=\mathrm{F}\left(\mathrm{K}_{\mathrm{T}}, \mathrm{L}_{\mathrm{T}}\right)$. Using the dual approach as before, TFP growth in sector $\mathrm{T}$ is given as: 
$\dot{g}_{T}=\frac{R K_{T}}{P_{T} Y_{T}}\left(\frac{\dot{r}}{r}\right)+\frac{W L_{T}}{P_{T} Y_{T}}\left(\frac{\dot{w}}{w}\right)$

which is equivalent to (A9) and (A10) except that (A15) represents TFP growth in sector T. The first two items are changes in the share-weighted nominal factor prices. The TFP is thus defined as the difference between the changes in factor prices and output prices.

The TFP for the whole economy is given as

$\dot{g}=\sum_{j} \mu^{j} \dot{g}_{j}$ with $\mu^{\mathrm{j}}=\mathrm{P}_{\mathrm{j}} \mathrm{Y}_{\mathrm{j}} / \mathrm{PY}$ for $\mathrm{j}=\mathrm{K}, \mathrm{H}, \mathrm{S}$, and $\mathrm{T}$.

Given data limitations to compute sector by sector TFP growth, it is assumed that the income shares between capital and labor are equal across sectors. Therefore, $g_{j}$ is estimated using the economy-wide income share between total capital and labor, each multiplied by the changes in factor prices. 


\section{Data Issues}

\section{Y: Real business GDP. Source: mainly CEIC data base.}

K: $\quad$ Productive capital stock (total capital less ICT capital and capital used in construction and, whenever available, agriculture). Capital stock was obtained using the perpetual inventory method. Except for China, Indonesia, and Malaysia where the required breakdown was not available, agriculture and construction were excluded from total GDP and capital stock. Source: CEIC data base.

ICT: Capital stock of Hardware, Software, and Telecommunication. Source: WITSA/IDC.

Hardware: The WITSA/IDC data are biased upward as they include household spending, which is (partly) offset by the exclusion of spending by unincorporated enterprises. Daveri (2000) found WITSA data to be biased upward for the United States and used a scale of 0.654. Schreyer (2000) concludes, however, that the two effects cancel out. In this study WITSA/IDC data were used without any adjustment.

Software: The WITSA/IDC data are much smaller than the U.S. BEA data; thus, we added half of internal IT services to the software data as reported by WITSA/IDC. Even then, the adjusted WITSA/IDC data show a fall in the magnitude of software investment during the period under examination, which contrasts with the increase in software investment in the U.S. data. Nevertheless, the WITSA/IDC data were used to maintain consistency with Asian economies for which the only available data source is the WITSA/IDC.

Telecommunications equipment: Although WITSA/IDC data on telecommunication includes spending for telecommunication services, it is not possible to separately identify the equipment. Therefore, total telecommunication spending for investment was used. There is, therefore, an upward bias on telecommunications investment that may in part compensate for the lower software investment.

q: Labor quality index was approximated by the average number of years of schooling. Source: CEIC data base.

Gross returns $\alpha$ 's were derived by adding the rate of depreciation to, then subtracting capital gains from, " $r$ " which is approximated by the real interest rate. Rates of depreciation of hardware, software, and telecommunications were assumed to be 44 percent, 32 percent, and 15 percent, respectively, based on Daveri (2000). Capital gains were obtained from the difference between the rate of growth of U.S. prices of ICT products and the investment deflator for each economy.

W: Wage rates were obtained from CEIC and the ILO. Sources: CEIC data base and ILO. 
Table A1. Estimating Contribution to Growth in the United States and Selected Asian Economies, 1990-99

\begin{tabular}{|c|c|c|c|c|c|c|c|c|c|c|}
\hline & \multicolumn{2}{|c|}{ U.S. } & \multicolumn{2}{|c|}{ Hong Kong SAR } & \multicolumn{2}{|c|}{ Indonesia } & \multicolumn{2}{|c|}{ Korea } & \multicolumn{2}{|c|}{ Malaysia } \\
\hline & 1990-94 & $1995-99$ & $1990-94$ & $1995-99$ & $1990-94$ & $1995-99$ & $1990-94$ & $1995-99$ & $1990-94$ & $1995-99$ \\
\hline \multicolumn{11}{|c|}{ As share of GDP } \\
\hline Non-ICT capital stock & 1.613 & 1.427 & 0.969 & 1.020 & 2.068 & 2.347 & 0.701 & 0.732 & 1.631 & 1.869 \\
\hline ICT capital stock & 0.146 & 0.135 & 0.146 & 0.214 & 0.030 & 0.023 & 0.129 & 0.135 & 0.088 & 0.083 \\
\hline Hardware & 0.026 & 0.025 & 0.017 & 0.019 & 0.004 & 0.003 & 0.031 & 0.025 & 0.013 & 0.012 \\
\hline Softwate & 0.024 & 0.020 & 0.007 & 0.007 & 0.000 & 0.000 & 0.007 & 0.005 & 0.007 & 0.005 \\
\hline Telecom & 0.096 & 0.091 & 0.121 & 0.188 & 0.025 & 0.019 & 0.091 & 0.105 & 0.067 & 0.066 \\
\hline \multicolumn{11}{|l|}{ Income share } \\
\hline Non-ICT capital stock & $0.23 \mathrm{t}$ & 0.228 & 0.136 & 0.138 & 0.392 & 0.270 & 0.100 & 0.125 & 0.260 & 0.288 \\
\hline ICT capital stock & 0.046 & 0.046 & 0.043 & 0.051 & 0.010 & 0.009 & 0.045 & 0.048 & 0.026 & 0.027 \\
\hline Hardware & 0.014 & 0.016 & 0.010 & 0.012 & 0.003 & 0.002 & 0.018 & 0.017 & 0.007 & 0.008 \\
\hline Software & 0.012 & 0.010 & 0.004 & 0.003 & 0.000 & 0.000 & 0.004 & 0.003 & 0.004 & 0.003 \\
\hline Telecom & 0.020 & 0.020 & 0,029 & 0.036 & 0.007 & 0.007 & 0.024 & 0.028 & 0.015 & 0.017 \\
\hline Labor & 0.723 & 0.726 & 0.821 & 0.812 & 0.598 & 0.720 & 0.855 & 0.826 & 0.714 & 0.685 \\
\hline \multicolumn{11}{|c|}{ Real return on capita! stock } \\
\hline Non-ICT capital stock & 0.143 & 0.160 & 0.140 & 0.135 & 0.190 & 0.120 & 0.142 & 0.171 & 0.159 & 0.154 \\
\hline ICT capital stork & 0.320 & 0.418 & 0.310 & 0.313 & 0.352 & 0.500 & 0.335 & 0.396 & 0.326 & 0.448 \\
\hline Hardware & 0.523 & 0.642 & 0.556 & 0.611 & 0.615 & 0.814 & 0.574 & 0.686 & 0.536 & 0.668 \\
\hline Software & 0.520 & 0.516 & 0.552 & 0.486 & 0.612 & 0.689 & 0.571 & 0.560 & 0.532 & 0.543 \\
\hline Telecom & 0.212 & 0.223 & 0.244 & 0.193 & 0.304 & 0.396 & 0.263 & 0.268 & 0.225 & 0.250 \\
\hline Return on total capital & 0.158 & 0.192 & 0.167 & 0.184 & 0,192 & 0.127 & 0.167 & 0.214 & 0.170 & 0.179 \\
\hline \multicolumn{11}{|c|}{ Contribution to growth } \\
\hline GDP & 2.012 & 3.635 & 5.021 & 2.103 & 8.513 & 1.260 & 7.960 & 5.902 & 9.396 & 5.118 \\
\hline Non-ICT capitai stock & 0.395 & 0.294 & 0.977 & 0.697 & 3.510 & 1.876 & 1.103 & 0.634 & 3.783 & 2.367 \\
\hline ICT capital stock & 0.265 & 0.785 & 0.862 & 1.168 & 0.147 & 0.186 & 0.901 & 1.103 & 0.427 & 0.566 \\
\hline Hardware & 0.153 & 0.655 & 0.274 & 0.443 & 0.053 & 0.087 & 0.449 & 0.650 & 0.169 & 0.341 \\
\hline Software & 0.026 & 0.029 & 0.054 & 0.022 & 0.003 & 0.006 & 0.053 & 0.018 & 0.047 & 0.011 \\
\hline Telecom & 0.086 & 0.101 & 0.534 & 0.703 & 0.090 & 0.093 & 0.399 & 0.435 & 0.210 & 0.214 \\
\hline Labor (hours) & 0.766 & 1.191 & 0.909 & 2.060 & 0.878 & 1.122 & 2.187 & 0.400 & 2.681 & 2.136 \\
\hline Labor (quality) & 0.237 & 0.109 & 1.790 & 0.537 & 1.819 & 2.381 & 1.636 & 0.763 & 4.232 & 1.163 \\
\hline TFP & 0.349 & 1.255 & 0.482 & -2.359 & 2.160 & -4.304 & 2.133 & 3.003 & -1.727 & -1.116 \\
\hline \multicolumn{11}{|c|}{ Labor productivity } \\
\hline GDP & 0.942 & 1.941 & 3.813 & -0.489 & 6.702 & -0.690 & 5.127 & 5.210 & 5.309 & 1.783 \\
\hline Non-ICT capital stock & 0.154 & -0.079 & 0.802 & 0.332 & 2.782 & 1.304 & 0.796 & 0.606 & 2.575 & 1.388 \\
\hline ICT capital stock & 0.202 & 0.598 & 0.725 & 0.902 & 0.119 & 0.146 & 0.691 & 0.937 & 0.287 & 0.412 \\
\hline Hardware & 0.126 & 0.520 & 0.225 & 0.344 & 0.043 & 0.065 & 0.345 & 0.519 & 0.120 & 0.254 \\
\hline Software & 0.013 & 0.012 & 0.046 & 0.013 & 0.002 & 0.005 & 0.039 & 0.017 & 0.028 & 0,003 \\
\hline Telecom & 0.063 & 0.066 & 0.454 & 0.546 & 0.074 & 0.077 & 0.307 & 0.401 & 0.139 & 0.155 \\
\hline Labor quality & 0.237 & 0.109 & 1.790 & 0.537 & 1.819 & 2.381 & 1.636 & 0.763 & 4.232 & 1.163 \\
\hline TFP & 0.349 & 1.313 & 0.496 & -2.260 & 1.982 & -4.521 & 2.005 & 2.905 & -1.785 & -1.181 \\
\hline \multicolumn{11}{|c|}{ Composition of TFP growth (using relative prices) } \\
\hline Total TFP & 0.349 & 1.255 & 0.482 & -2.359 & 2.160 & .4 .304 & 2.133 & 3.003 & -1.727 & -1.116 \\
\hline ICT sector & 0.225 & 0.413 & 0.595 & 0.413 & 0.075 & 0.629 & 0.356 & 0.658 & 0.562 & 3.471 \\
\hline Hardware & 0.208 & 0.397 & 0.531 & 0.407 & 0.057 & 0.474 & 0.293 & 0.593 & 0.527 & 3.328 \\
\hline Telecommunications & 0.017 & 0.016 & 0.064 & 0.005 & 0.018 & 0.155 & 0.063 & 0.065 & 0.035 & 0.143 \\
\hline All other sectors & 0.125 & 0.843 & -0.113 & $-2.77 !$ & 2.085 & -4.934 & 1.777 & 2.345 & -2.288 & -4.586 \\
\hline \multicolumn{11}{|c|}{ Composition of TFP growth (using weighted average real factor prices) } \\
\hline Total TFP & 0.349 & 1.255 & 0.482 & -2.359 & 2.160 & $-4,304$ & 2.133 & 3.003 & -1.727 & -1.116 \\
\hline ICT sector & 0.016 & 0.050 & -0.045 & 0.051 & -0.003 & 0.510 & 0.082 & -0.056 & -0.062 & 0.270 \\
\hline Hardware & 0.015 & 0.058 & -0.001 & 0.050 & -0.001 & 0.138 & 0.049 & 0.032 & .0 .022 & 0.180 \\
\hline Telecommunications & 0.001 & -0.008 & -0.044 & 0.000 & .0 .002 & 0.372 & 0.033 & -0.088 & -0.040 & 0.089 \\
\hline All other sectors & 0.333 & 1.205 & 0.527 & -2.409 & 2.163 & -4.814 & 2.051 & 3.059 & -1.664 & -1.385 \\
\hline
\end{tabular}


Table A1. Estimating Contribution to Growth in the United States and Selected Asian Economies, 1990-99 (Concluded)

\begin{tabular}{|c|c|c|c|c|c|c|c|c|c|c|c|c|}
\hline & \multicolumn{2}{|c|}{ Philippines } & \multicolumn{2}{|c|}{ Singapore } & \multicolumn{2}{|c|}{ Taiwan POC } & \multicolumn{2}{|c|}{ Thailand } & \multicolumn{2}{|c|}{ India } & \multicolumn{2}{|c|}{ China } \\
\hline & $1990-94$ & $1995-99$ & $1990-94$ & $1995-99$ & 1990.94 & $1995-99$ & $1990-94$ & $1995-99$ & $1990-94$ & $1995-99$ & $1990-94$ & $1995-99$ \\
\hline \multicolumn{13}{|c|}{ As share of GDP } \\
\hline Non-ICT capital siock & 1.234 & 1.126 & 0.732 & 0.707 & 1.263 & 1.290 & 1.090 & 1.387 & 1.294 & 0.895 & 1.639 & 1.773 \\
\hline ICT capital stock & 0.026 & 0.030 & 0.209 & 0.219 & 0.094 & 0.106 & 0.044 & 0.040 & 0.015 & 0.014 & 0.011 & 0.018 \\
\hline Hardware & 0.003 & 0.005 & 0.038 & 0.033 & 0.012 & 0.011 & 0,008 & 0.006 & 0.002 & 0.002 & 0.003 & 0.003 \\
\hline Software & 0.002 & 0.002 & 0.019 & 0.015 & 0.004 & 0.004 & 0.004 & 0.002 & 0.001 & 0,000 & 0.000 & 0.000 \\
\hline Telecom & 0.021 & 0.024 & 0.152 & 0.171 & 0.078 & 0,090 & 0.033 & 0,032 & 0.012 & 0.012 & 0.007 & 0.015 \\
\hline \multicolumn{13}{|l|}{ frecome share } \\
\hline Non-SCT capital stock & 0.223 & 0.193 & 0.101 & 0.109 & 0.187 & 0.201 & 0.195 & 0.244 & 0.215 & 0.137 & 0.271 & 0.296 \\
\hline ICT capital stock & 0.010 & 0.011 & 0.060 & 0.064 & 0.025 & 0.029 & 0.015 & 0.015 & 0.005 & 0.003 & 0.004 & 0.006 \\
\hline Hatdwate & 0.002 & 0.003 & 0.020 & 0.021 & 0.006 & 0.007 & 0.005 & 0.004 & 0.001 & 0.001 & 0.002 & 0.002 \\
\hline Software & 0.001 & 0.001 & 0.010 & 0.007 & 0.002 & 0.002 & 0.002 & 0.001 & 0.000 & 0.000 & 0,000 & 0.000 \\
\hline Telecom & 0.007 & 0.006 & 0.031 & 0.036 & 0.017 & 0.020 & 0,009 & 0.010 & 0.003 & 0.002 & 0.002 & 0.004 \\
\hline Labor & 0.768 & 0.796 & 0.839 & 0.827 & 0.788 & 0.771 & 0.790 & 0.741 & 0.780 & 0.860 & 0.725 & 0.699 \\
\hline \multicolumn{13}{|c|}{ Real retum on capital stock } \\
\hline Non-ICT capital stuck & 0.181 & 0.171 & 0.138 & 0.153 & 0.148 & 0.156 & 0.179 & 0.176 & 0.165 & 0.153 & 0.165 & 0.167 \\
\hline ICT capital stock & 0.421 & 0.518 & 0.305 & 0.392 & 0.250 & 0.286 & 0.373 & 0.495 & 0.296 & 0.274 & 0.431 & 0.431 \\
\hline Hatdware & 0.628 & 0.693 & 0.515 & 0.628 & 0.525 & 0.635 & 0.577 & 0.723 & 0.555 & 0.583 & 0.629 & 0.673 \\
\hline Software & 0.624 & 0.567 & 0.511 & 0.503 & 0.521 & 0.509 & 0.573 & 0.597 & 0.551 & 0.457 & 0.625 & 0.548 \\
\hline Telecom & 0.316 & 0.275 & 0.204 & 0.210 & 0.213 & 0.216 & 0.265 & 0.305 & 0.243 & 0,165 & 0.318 & 0.255 \\
\hline Return on total capital & 0.191 & 0.213 & 0.179 & 0.235 & 0.154 & 0.166 & 0.189 & 0.197 & 0.167 & 0.155 & 0.168 & 0.175 \\
\hline \multicolumn{13}{|c|}{ Contribution to growth } \\
\hline GDP & 2.725 & 4.960 & 8.759 & 5.549 & 6.917 & 6.456 & 9.589 & 1.885 & 5.220 & 6.558 & 10,633 & 8.760 \\
\hline Non-ICT capitgl stock & 0.784 & 0.725 & 0.956 & 0.656 & 1.868 & 1.668 & 2.803 & 1.108 & 1.615 & 1.499 & 3.226 & 3.392 \\
\hline ICT capital stock & 0.176 & 0.314 & 0.944 & 1.358 & 0.401 & 0.580 & 0.224 & 0.225 & 0,056 & 0.107 & 0.137 & 0.269 \\
\hline Hardware & 0.066 & 0.195 & 0.390 & 0.839 & 0.121 & 0.305 & 0.084 & 0.141 & 0.020 & 0.048 & 0.046 & 0.118 \\
\hline Software & 0.015 & 0.011 & 0.099 & 0.040 & 0.030 & 0.020 & 0.023 & +0.001 & 0.003 & 0.004 & 0.003 & 0.002 \\
\hline Telecom & 0.096 & 0.108 & 0.455 & 0.479 & 0.250 & 0.255 & 0.117 & 0.084 & 0.033 & 0.054 & 0.089 & 0.150 \\
\hline Labor (hours) & 2.182 & 2.195 & 2.841 & 2.262 & 1.212 & 0.934 & 1.153 & 0.428 & 0.772 & 0.447 & 2.678 & 0.687 \\
\hline Labor (quality) & 0.660 & 0.612 & 5.581 & 1.556 & 1.215 & 0.985 & 3.196 & 0.951 & 2.012 & 2.341 & 1.101 & 0.652 \\
\hline TFP & -1.078 & 1.113 & -1.563 & -0.282 & 2.221 & 2.290 & 4.212 & -0.826 & 0.766 & 2.164 & 3.490 & 3.761 \\
\hline \multicolumn{13}{|c|}{ Labor productivity } \\
\hline GDP & -0.124 & 2,123 & 5.035 & 2.678 & 5.169 & 5.040 & 7.803 & 1.211 & 4,092 & 5.817 & 6.630 & 7.408 \\
\hline Non-ICT capital s1ock & 0.152 & 0.194 & 0,576 & 0.350 & 1.501 & 1.351 & 2.378 & 0.994 & 1.351 & 1.338 & 2.162 & 2.915 \\
\hline ICT capital stock & 0.130 & 0.230 & 0.657 & 1.015 & 0.333 & 0.474 & 0.185 & 0.194 & 0.047 & 0.088 & 0.101 & 0.211 \\
\hline Hardware & 0.048 & 0.139 & 0.280 & 0.640 & 0.101 & 0.243 & 0.068 & 0.114 & 0.016 & 0.039 & 0.032 & 0.090 \\
\hline Sottware & 0.011 & 0.008 & 0.058 & 0.019 & 0.024 & 0.017 & 0.019 & -0.002 & 0.002 & 0.003 & 0.002 & 0.002 \\
\hline Telecam & 0.071 & 0.083 & 0.319 & 0.355 & 0.208 & 0.215 & 0.098 & 0.081 & 0.029 & 0.046 & 0.067 & 0.120 \\
\hline Labor quality & 0.660 & 0.612 & 5.581 & 1.556 & 1.215 & 0.985 & 1.196 & 0.951 & 2.012 & 2.341 & 1.101 & 0.652 \\
\hline TFP & -1.066 & 1.088 & -1.779 & -0.243 & 2.120 & 2.230 & 4.043 & -0.928 & 0.683 & 2.050 & 3.265 & 3.629 \\
\hline \multicolumn{13}{|c|}{ Composition of TFP gruwh (using relative prices) } \\
\hline Totni TFP & -1.078 & 1.113 & -1.563 & -0.282 & 2.221 & 2.290 & 4,212 & -0.826 & 0.766 & 2.164 & 3.490 & 3.761 \\
\hline ICT sector & 0.205 & 0.648 & 3.440 & 7.036 & 0.657 & 1.900 & 0.416 & 1.902 & 0.073 & 0.048 & & \\
\hline Hardware & 0.131 & 0.604 & 3.410 & 7.022 & 0.646 & 1.889 & 0.402 & 1.845 & 0.055 & 0.059 & & \\
\hline Telecommunications & 0.074 & 0.044 & 0.030 & 0.014 & 0.011 & 0.011 & 0.014 & 0,057 & $0.0[9$ & -0.011 & & \\
\hline All other sectors & $-\{.283$ & 0.465 & -5.004 & -7.318 & 1.564 & 0.390 & 3.796 & -2.728 & 0.693 & 2.116 & & \\
\hline \multicolumn{13}{|c|}{ Composition of TFP growth (using weighted average real factor prices) } \\
\hline Total TFP & -1.078 & 1.113 & -3.563 & -0.282 & 2.2 .21 & 2.290 & 4.212 & -0.826 & 0.766 & 2.164 & 3.490 & 3.761 \\
\hline KCT sector & -0.001 & -0.020 & 0.290 & 1.737 & 0.020 & 0.426 & $-0,008$ & 0.195 & .0 .068 & 0.046 & & \\
\hline Hardware & -0.001 & 0.001 & 0.306 & 1.684 & 0.037 & 0.381 & -0.001 & 0.181 & -0.017 & 0.023 & & \\
\hline Telecommunications & 0.001 & -0.021 & -0.016 & 0.053 & -0.018 & 0.045 & -0.007 & 0.013 & -0.052 & 0.023 & & \\
\hline All pther sectors & -1.077 & 1.134 & -1.853 & -2.019 & 2.201 & 1.864 & 4.221 & $\cdot 1.021$ & 0.834 & 2.118 & & \\
\hline
\end{tabular}

Source: IMF estimates. 


\section{References}

Bassanini, Andrea, Stefano Scarpetta and Ignazio Visco, 2000, "Knowledge, Technology and Economic Growth: Recent Evidence from OECD Countries," OECD Working Paper, No. 259 (Paris: Organization for Economic Cooperation and Development).

Bosworth, Barry and Jack Triplett, 2000, "What's New About the New Economy? IT, Economic growth and Productivity," Brooking Institution, available at: (http://www.brook.edu/views/papers/bosworth/20001020.htm).

Cardarelli, Roberto, 2001, "Is Australia a 'New Economy'?" in Australia: Selected Issues and Statistical Appendix, IMF Country Report No. 01/55 (Washington: International Monetary Fund).

Daveri, Francesco, 2000, "Is Growth an Information Technology Story in Europe Too?" IGIER Working Paper No. 168 (Milan: Innocenzo Gasparini Instititute for Economic Research).

Goldman Sachs, 2000, "The IT Revolution-New Data on the Global Impact," Global Economics Weekly, October 18.

Gordon, Robert J., 2000, "Does the 'New Economy' Measure up to the Great Inventions of the Past?” Journal of Economic Perspectives, Vol. 14 (Fall), pp. 49-74.

International Monetary Fund, 2001, World Economic Outlook, October (Washington).

Jorgenson, Dale W., and Kevin J. Stiroh, 2000, "Raising the Speed Limit: U.S. Economic Growth in the Information Age," Brookings Papers on Economic Activity: 1, Brookings Institution, pp. 161-67.

Lee, Il Houng, and Yougesh Khatri, 2001, "The Role of the New Economy in East Asia," (unpublished; Washington: International Monetary Fund, Asia and Pacific Department).

Oliner, Stephen D., and Daniel E. Sichel, 2000, "The Resurgence of Growth in the Late 1990s: Is Information Technology the Story," Journal of Economic Perspectives, Vol. 14 (Fall), pp. 3-22. 